\title{
Oinezkoen simulazioak giza indarraren ereduaren bidez: larrialdi-egoerak
}

\author{
(Pedestrian Dynamics simulations using the Social Force Model: \\ emergency situations)
}

\author{
Ibon Barrio Ugidos*, Josu Mirena Igartua Aldamiz
}

Fisika Aplikatua II Saila. Zientzia eta Teknologia Fakultatea (UPV/EHU)

\begin{abstract}
LABURPENA: Oinezkoentzako inguruneetan, metroetako pasabideetan edo merkataritzaguneetan esaterako, jende ugari pilatzen da. Ibiltarien segurtasuna arriskuan ipintzen du horrek, bereziki larrialdi-egoeretan. Ondorioz, oinezkoen dinamika aztertzeak berebiziko garrantzia dauka. Lan honetan jendetzaren dinamika modelizatzen duen ereduetako bat landu da, giza indarraren eredua alegia. Besteak beste, eredu horren formulazio matematikoa, aplikagarritasun-esparruak, mugak eta datu esperimentalekiko erlazioa aztertu dira. Gainera, eredu horren bitartez irteera bakarreko gela baten ebakuazioa aztertu da, ibiltarien hustutze prozesuan oztopoek nola eragiten duten ikusteko. Ate ondoan ezaugarri bereziak dituen horma edo zutabe bat kokatzeak irtete-denbora murrizten duela egiaztatu da, oztopoek oinezkoen fluxua ordenatzen dutelako. Bestalde, horma luze baten ordez zutabeen edo horma txikien ilara bat eratu daiteke emaitzak are gehiago hobetzeko.
\end{abstract}

HITZ GAKOAK: Giza indarraren eredua, Larrialdi-egoerak, Oinezkoak.

ABSTRACT: Pedestrian areas such as underground stations or shopping centres are more often than not overcrowded. In case of emergency, the safety of pedestrians is called into question. As a matter of fact, the analysis of pedestrian flows is highly meaningful. This study is developed following the Social Force Model, a perspective on modelling of crowd dynamics and pedestrian motion. The mathematical formulation, fields of applications, limits and the relation with experimental data have been considered. Moreover, a simulated evacuation of a single-exit room has been analysed, together with the influence of obstacles in the event of an emergency evacuation procedure. It has been proven that placing a wall or a column with special features can help reducing the evacuation time because the obstacles tend to organize the flow. In addition replacing a long wall by a row of columns or small walls can even improve the results.

KEYWORDS: Social Force Model, Emergency situations, Pedestrians.

* Harremanetan jartzeko / Corresponding author: Ibon Barrio Ugidos. Fisika Aplikatua II Saila, Zientzia eta Teknologia Fakultatea, UPV/EHU, Sarriena Auzoa (48940 Leioa, Euskal Herria). - ibarrio012@ikasle.ehu.eus - https://orcid.org/

Nola aipatu / How to cite: Barrio Ugidos, Ibon; Igartua Aldamiz, Josu Mirena (2021). «Oinezkoen simulazioak giza indarraren ereduaren bidez: larrialdi-egoerak»; Ekaia, 39, 2021, 277-298. (https://doi.org/10.1387/ekaia.21885).

Jasoa: 2020, uztailak 1; Onartua: 2020, urriak 8.

ISSN 0214-9001 - elSSN 2444-3255 / (c) 2021 UPV/EHU

(c) (i) () Obra hau Creative Commons Atribución 4.0 Internacional-en lizentziapean dago 


\section{SARRERA}

Oinezkoentzako inguruneak pertsonak oinez mugitzeko eremu publiko edo pribatuak dira. Horien adibide dira metroetako pasabideak, parkeak, aireportuak edo merkataritza guneak, esaterako. Maiz toki horiek bete egiten dira, daukaten eskari handia dela eta. Oinezkoen segurtasuna arriskuan jartzen du horrek, bai ohiko baldintzetan baita larrialdi kasuetan ere [1]. Testuinguru horretan, eta gaur egungo gizartearen arazoei aurre egiteko, diziplinarteko ikuspegi baten beharra dagoela jakinda, azkeneko urteetan soziofisika nabarmen garatu da. Fisikaren alor horrek fisika estatistikoa eta soziologia uztartzen ditu, banakoak, egitura sozial baten unitate gisa, beste pertsonekin dituen interakzioen ondorioz sortutako fenomenoak aztertzeko. Oinezkoen dinamikaren azterketak segurtasuna hobetzeko erabil daitezke eta, beraz, fisikaren bidez ongizatearen funtsezko oinarria den esparru horretan lagundu [2].

Nahiz eta pentsa daitekeen oinezkoen portaerak ordenarik ez duela eta hori dela eta, fisikako eredu baten bidez hori modelizatzea zaila dela, fluxuetan patroiak agertzen direla ikusi da. Oinezkoen dentsitatearen arabera, esaterako, ikusi dira egoera gaseosoak (ibiltari kopuru txikia eta libreki higitu daitezkeenean), fluidoak (oztopoduna) eta solidoak (ibiltari kopuru oso handia eta ia higitu ezin direnean). Horrez gainera, ibiltarien jokaerak zenbait ezaugarri dituela hauteman da. Alde batetik, gune pertsonalaren efektua. Horren arabera, oinezkoak deseroso sentitzen dira beste ibiltariengandik gertu higitu behar direnean eta, beraz, kulturaren eta erlijioaren araberakoa den distantzia interpertsonal bat mantentzen saiatzen dira. Beste alde batetik, auto-antolatzeko portaera daukate pertsonek. Hori egoera desberdinetan ikusi da. Noranzko bakarrekoa eta homogeneoa denean fluxua, hau da, ibiltari guztiek ezaugarri berdinak dituztenean, ilaretan antolatzen dira oinezkoak. Izan ere, batak bestea aurreratzea ekiditen du homogeneotasun horrek. Noranzko bakarreko fluxu hetereogeneoaren kasuan, aldiz, abiadura edo norabide-aldaketak oinezko baten egoera hobetu dezake. Dena dela, onura handia ez bada, oinezkoak nahiago du abiadura moteldu eta beste baten atzetik joan, horrela oztopoekin talka egiteko probabilitatea murrizten delako. Teoriak, beraz, abiadura bereko fluxu homogeneoen eraketak aurresaten ditu. Bukatzeko, bi noranzkoko fluxuen kasuan, noranzko bereko lerro dinamikoak eratuz antolatzen dira oinezkoak. Korridorea bi gunetan banatzen denean gertatzen da kasu optimoa: eremuetako batean noranzko bereko lerroak korronte-fluxu bat eratzen dute eta, bestean, kontrako noranzkokoak. Modu horretan, korronteen arteko marruskadura bi korronteen arteko mugan baino ez da gertatzen. Interesgarria da aipatzea, korronte dinamiko horiek autoek zirkulatzen duten alde berean eratzen direla eta, beraz, herrialdeen arabera aldatu egiten dira [1, 3, 4].

Ezaugarri, patroi eta ebidentzia horiek erreproduzitzeko, historian zehar ereduak proposatu dira. Eraikinen plangintzaren eta suteen babesa- 
ren arloetan topa daiteke oinezkoen fluxuen azterketaren jatorria. Hala ere, oinezkoen dinamikaren azterketaren jatorria 50eko hamarkadan koka dezakegu [5].

Lehenengo eredu fisikoa 1971. urtean proposatu zen [6]. Horretan, oinezkoen fluxuak gasen eta fluidoen antzekoak zirela jotzen zen eta, ondorioz, harreman zuzena zuten Navier-Stokes ekuazioekin. Gasen zinematikaren eta fluidoen dinamikaren teoria erabilia izan da horrez geroztik ibiltarien jokaera aztertzeko [7, 8, 9]. Horrek arazo handia dauka, izan ere ez ditu aintzat hartzen talkak saihesteko maniobrak, zeinetan energia eta momentua kontserbatzen ez diren. Horrez gainera, ez dute oinezkoen natura-pikortasuna kontsideratzen: oinezko bakoitzak bolumen zehatz bat betetzen du eta gainerakoak ezin dira horretan sartu. Horren guztiaren ondorioz, azken urteotan eredu mikroskopikoak izan dira arrakastatsuenak. Horien barruan, Cellular Automata (CA) $[10,11]$ eta Social Force Model (SFM) dira aipagarrienak.

Lan honetan Social Force Model aztertuko da. Besteak beste, aztertuko dira eredu horren formulazio matematikoa, aplikagarritasun-esparruak, mugak eta datu esperimentalekiko erlazioa. Gainera, programazio-lengoai baten laguntzarekin, Python delakoarekin alegia, eredua frogatzeko eta oinarrizko ebidentzia esperimentalak betetzen diren ala ez ikusteko zenbait simulazio egingo da.

\section{SOCIAL FORCE MODEL (SFM)}

Eredua 1995. urtean proposatu zuten Helbingek eta bere kideek [12]. Oinezkoetan eragiten duten irudizko giza indarretan, «social force» direlakoetan, dago oinarrituta. Giza elkarrekintzen ondorioz (fisikako elkarrekintza edo eremuen ordez) azelerazioa edo dezelerazio efektua deskribatzen dituzten bektoreak dira giza indarrak. Indar horiek oinezkoaren higidura zehazten dute.

Oinezkoen arteko elkarrekintzak, auto-antolamendu efektuak eta jendetzaren presio handiak era errealistan deskribatzen ditu SFM ereduak. Haren desabantaila handiena da konputazionalki esfortzu handia eskatzen duela.

Eredu honetan oinezkoen higidura-ekuazio diferentzial arrunt baten bidez deskribatzen da:

$$
m_{i} \frac{\vec{v}_{i}}{d t}=\vec{F}_{i, t o t}+\xi
$$

Adierazpen horretan, $i=1,2, \ldots, N$ azpiindizeak oinezkoa adierazten du; $m_{i}$ da $i$. oinezkoaren masa. Newtonen bigarren legea dugu, $\xi$ gai osagarri batekin. Fluktuazioak deskribatzeko sartzen da hori, oinezkoak ohiko 
jarreratik urruntzen diren jokabidea adierazteko (ingurunearekin entretenitzen direnean, giza jokaerek irregulartasun edota inperfekzio-gradua daukate...). Lan honetan gai hori ez da kontuan hartuko, bi arrazoirengatik: alde batetik, oinezkoen zirkulazioa orokorrean sistematikoa delako eta, beraz, gai hori txikia da atal deterministaren aldean; bestetik, gai horren arbuiaketak eredua sinplifikatzen laguntzen duelako. $\vec{F}_{i, t o t}$ delakoak ingurunearen efektua deskribatzen du eta $i$. oinezkoarengan eragiten du. Hainbat atalez osatuta dago:

$$
\vec{F}_{i, t o t}=\vec{F}_{i}^{d}+\sum_{i \neq j} \vec{F}_{i j}^{r}+\sum_{w} \vec{F}_{i w}+\sum_{g} \vec{F}_{i g}^{a}
$$

Ekuazio horretan $\vec{F}_{i}^{d}$ da oinezkoaren helbururantz zuzendutako higidura-indarra; $\sum_{i \neq j} \vec{F}_{i j}^{r}$ oinezkoak $i$. oinezkoari eragindako indar alderatzailea; $\sum_{w} \vec{F}_{i w}$ da $\omega$ objektuak (hormak, kaleko oztopoak) $i$. oinezkoari eragindako indarra eta $\sum_{g} \vec{F}_{i g}^{a}$, pertsona edo objektu bati eragindako erakarpena. Azken gai hori lan honetan ez da kontuan hartuko; izan ere, gainerako ekarpenekin nahikoa da aztertu nahi diren efektuak deskribatzeko. Gainera, indar gehiago kontsideratzean kalibratu beharreko konstante kopurua handitu egiten da, eta eredua zailtzen. Hala ere, aipatu beharra dago indar hori arbuiatzean, oinezkoak banako independenteak direla kontsideratzen ari garela; beraz, talde-portaerak, hiru oinezko elkarrekin ibiltzea eta komunikatzea, adibidez, ez direla aintzat hartu [13].

\subsection{Indar abiarazlea}

Bere tarteko helmugetara eta amaierako helmugara zuzentzen du oinezkoa indar horrek. Honako formakoa da:

$$
\vec{F}_{i}^{d}(t)=m \cdot \frac{v_{i}^{0}(t) \vec{e}_{i}^{0}-\vec{v}_{i}(t)}{\alpha_{i}}
$$

Adierazpen horretan $v_{i}^{0}$ eta $e_{i}^{0}$ dira oinezkoak desiratutako abiadura eta noranzkoa; $\vec{v}_{i}(t)$ da aldiuneko abiadura eta, $\alpha$ erlajazio-denbora. 3. ekuazioaren arabera, aldiuneko abiadura desiratutako abiadura baino handiagoa edo txikiagoa bada, ibiltariak desiratutako abiadura eta noranzkoak berreskuratzen ditu denbora karakteristikoan. Denbora tarte horretan bai gizakion erreakzio-denbora bai azeleratzeko behar duguna barne daude. 


\subsection{Oinezkoen arteko indarra}

Ibiltarien arteko elkarrekintza deskribatzen du indar horrek. Dakigun moduan, oinezkoek ibiltzeko espazio propio bat edukitzen dute eta, ondorioz, indar hori alderatzailea da. Hurrengo forma dauka:

$$
\vec{F}_{i j}^{r}\left(d_{i j}\right)=A_{i} e^{\frac{r_{i j}-d_{i j}}{B_{i}}} \vec{e}_{i j}
$$

Konstanteak dira $A_{i}$ eta $B_{i}$. Berreturako $r_{i j}=r_{i}+r_{j}$ da $i$. eta $j$. oinezkoen erradioen batura, $d_{i j}=\left\|\vec{r}_{i}-\vec{r}_{j}\right\|$, $i$. eta $j$. oinezkoen masa-zentroen arteko distantzia eta $\vec{e}_{i j} j$. oinezkotik $i$. ibiltarira zuzendutako bektore unitarioa. Indar horrek oinezkoen arteko distantziarekiko mendekotasun esponentziala adierazten du eta indarra zerorantz doa ibiltariak elkarrengandik asko urruntzen badira. $A_{i}$ konstantea elkarrekintzaren intentsitatearekin dago lotuta eta $B_{i}$ elkarrekintza tartearekin.

Lan honetan, karga konputazionala arintzeko, hurrengo moduan definituko da indar alderatzailea:

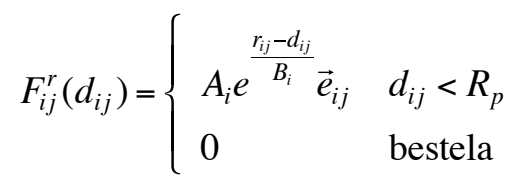

Adierazpen horretan, $R_{p}$ da alderatze-erradioa. Horren arabera, oinezko baten alderatze-erradio horretatik kanpo baldin badago beste oinezko bat, lehenengoak ez dio inolako indarrik eragingo bigarrenari, ez du ikusiko. Alderatze-erradio hori kontsideratzeak, ez dauka lortutako emaitzetan ondorio adierazgarririk, urrun dauden ibiltarien ekarpena oso txikia delako.

\subsection{Hormek eragindako indarra}

Horma eta oztopoetatik urruntzen saiatzen dira oinezkoak. Fenomeno hori deskribatzeko honako indarra daukagu:

$$
\vec{F}_{i w}=A_{i, w} e^{\frac{r_{i}-a_{i w}}{B_{i, w}}}
$$

Ekuazio horretan $A_{i, w}$ eta $B_{i, w}$ konstanteak dira; $d_{i W}$ da $i$. oinezkoaren eta paretaren arteko distantzia eta, $r_{i} i$. ibiltariaren erradioa. Oinezko-oinezko elkarrekintzaren oso antzekoa da. Hala ere, desberdintasun garrantzitsu bat dago: ibiltariak erradio karakteristiko bat daukaten zirkulutzat deskribatzen diren bitartean, horma eta oztopoak elementu puntualtzat hartzen dira. 


\subsection{Bestelako gaiak eta ñabardurak}

\section{Abiaduraren mugapena}

1995. urtean proposatutako ereduak ez dauka inolako mugapenik oinezkoen abiaduran. Horrek arazoak ekar ditzake; izan ere, bi ibiltari elkarrekiko oso gertu daudenean, indar alderatzaile oso handiak agertzen dira eta, beraz, abiadura erraldoiak.

Ondorioz, abiadura maximo bat zehaztea ezinbestekoa da, errealistak ez diren efektu horiek ekiditeko. Beraz, abiadura:

$$
\vec{v}_{i}(t)=\vec{v}_{i} \cdot g\left(\frac{v_{\max }}{\left\|\vec{v}_{i}\right\|}\right)
$$

da. 7 adierazpeneko $g$ funtzioa hurrengo moduan definitzen da:

$$
g\left(\frac{v_{\max }}{\left\|\vec{v}_{i}\right\|}\right)= \begin{cases}1 & \left\|\vec{v}_{i}\right\| \leq v_{\max } \\ \frac{v_{\max }}{\left\|\vec{v}_{i}\right\|} & \text { bestela }\end{cases}
$$

Horrek esan nahi du indar erresultantea kalkulatu ondoren oinezkoaren abiaduraren moduluak $v_{\max }$ gainditzen badu, orduan, abiadurak $x$ eta $y$ osagaien arteko erlazioari eutsiko diola, baina modulua lor dezakeen maximoaren berdina izango dela [14].

\section{Anisotropia}

Oinezkoek ez dute bere ingurunea homogeneoki norabide guztietan hautematen [15]. Gure ibiltzeko modua ikusten dugunaren araberako da eta argi eta garbi, gure aurrez aurre dagoenak eragin handiagoa dauka. Anisotropia hori kontuan hartzeko, oinezkoen arteko elkarrekintza, hots, 5 adierazpena, angeluaren mendekoa den pisu batez $\omega\left(\theta_{i j}\right)$ biderkatzen da:

$$
w\left(\theta_{i j}\right)=\lambda+(1-\lambda) \frac{1+\cos \left(\theta_{i j}\right)}{2} \quad \text { non } \quad \theta_{i j} \in[-\pi, \pi]
$$

1. irudian ikus daitekeen moduan, $\lambda=1$ denean, norabide guztiak guztiz baliokideak dira. $\lambda=0$ denean, ordea, aurrean dauden oinezkoek ekarpen handiagoa daukate atzean daudenek baino.

Datu esperimentalen kalibrazio ebolutiboaren bidez $\lambda \approx 0.1$ proposatu da [16]. 


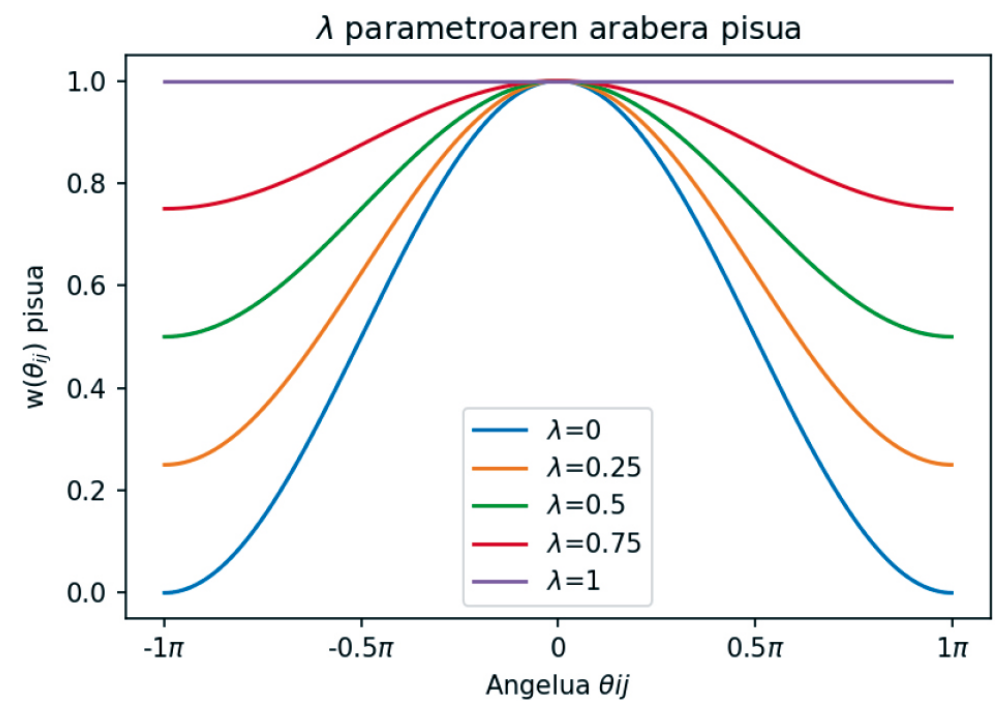

1. irudia. Anisotropia.

\section{Larrialdi-egoerak}

Larrialdi egoerek ezaugarri bereziak dituzte (dentsitate handia, ibiltariak ohi baino arinago saiatzen dira higitzen, elkarrekintza fisikoak egoten dira, etab) eta, ondorioz, ereduaren ekuazioak moldatu behar dira [17]. Oinezkoen arteko elkarrekintzan, ohiko 4 ekuazioari beste bi gai gehitu behar zaizkio, dentsitate handien ondorioz gainezarpenak eta ibiltarien arteko marruskadura hobeto adierazteko:

$$
\vec{F}_{i j}^{r}\left(d_{i j}\right)=A_{i} e^{\frac{r_{i j}-d_{i j}}{B_{i}}} \vec{e}_{i j}+k g\left(r_{i j}-d_{i j}\right) \vec{n}_{i j}+\kappa g\left(r_{i j}-d_{i j}\right) \Delta v_{j i}^{t} \vec{t}_{i j}
$$

Adierazpen horretan, $k$ eta $\varkappa$ konstanteak dira. $g(x)$ funtzioa $g(x)=x$ da $x>0$ denean eta, bestela, $g(x)=0 . \vec{n}_{i j}=\left(\vec{n}_{i j}^{1}, \vec{n}_{i j}^{2}\right)=\left(\left(\vec{r}_{i}-\vec{r}_{j}\right) / d_{i j}\right)$, j. oinezkotik $i$. oinezkora zuzenduta dagoen bektore normala da eta $\vec{t}_{i j}=\left(-\vec{n}_{i j}^{2}, \vec{n}_{i j}^{1}\right)$, ordea, $\vec{n}_{i j}$ bektorearekiko perpendikularra. Gainera, $\Delta v_{j i}^{t}\left(\vec{v}_{j}-\vec{v}_{i}\right) \vec{t}_{i j}$ abiadura tangentzialen arteko diferentzia da.

Gehitutako lehenengo gaia, $k g\left(r_{i j}-d_{i j}\right) \vec{n}_{i j}$, gorputz indarra da. Malguki baten forma dauka, $k$ konstante elastikoduna eta oinezkoak aldentzen diren heinean linealki indargabetzen da. Haren funtzioa, oinezkoak elkarren- 
gandik oso hurbil daudenean, haien arteko konpresio horri aurka egitea da. Bestalde, $\kappa g\left(r_{i j}-d_{i j}\right) \Delta v_{j i}^{t} \vec{t}_{i j}$, labainketa frikzioa da, pertsonak gainezartzen direnean higidura tangentziala zein zaila den adierazten duena.

Larrialdi-kasuetan, oinezkoen arteko elkarrekintzari bi gai horiek sartzeaz gain, oinezko horma interakzioari, hots, 6 ekuazioari ere, bi gai baliokide gehitu behar zaizkio:

$$
\vec{F}_{i}^{w}\left(d_{i j}\right)=A_{i} e^{\frac{r_{i}-d_{i W}}{B_{i}}}+k g\left(r_{i}-d_{i W}\right) \vec{n}_{i W}-\kappa g\left(r_{i}-d_{i W}\right)\left(\vec{v}_{i} \vec{t}_{i W}\right) \vec{t}_{i W}
$$

\section{Konstanteen zehaztapena}

Ereduko konstante ezberdinak zehazteko datu esperimentalak ezinbestekoak dira eta, horregatik, esperimentu ugari egiten dira laborategiko baldintzetan eredu matematikoak kuantitatiboki baliagarriak diren egiaztatzeko. Datu esperimentalak lortzeko, metodo desberdinak erabiltzen dira, hala nola, bideoaren bidezko jarraipena. Horietan oinezkoen ibilbidea grabatu edo jaso egiten da sentsore infragorrien bitartez, esaterako. Behin datuak eskuratuta, algoritmoen bidez, konstanteak zehaztu egiten dira. Algoritmo horietan $i$ ibiltari bat hartu eta ereduaren ekuazioei jarraituz mugitu egiten da; gainerako oinezko guztiak, aldiz, bideoek erakutsitako ibilbideak dituzte. Prozedura hori oinezko guztiekin egiten da, eta azkenean, ereduaren eta bideoaren arteko errorea minimizatzen dituzten konstanteen balioak bilatzen dira. Gainera, datuak zenbait fluxu-dentsitateren diagramekin bat datozen ala ez aztertzen da. Lan honetan, bibliografian ohikoak diren hurrengo balioak aukeratu dira, esperimentalki kasu sinpleetan egokiak direla frogatu ondoren $[16,18]$

1. taula. Erabili diren parametroen balioak

\begin{tabular}{ccc}
\hline Parametroa & Balioa & Unitatea \\
\hline$\alpha$ & 0.5 & $\mathrm{~s}$ \\
$R_{p}$ & 2.5 & $\mathrm{~m}$ \\
$r_{i}$ & {$[0.25,0.35]$} & $\mathrm{m}$ \\
$v_{i}^{0}$ & {$[1.35,1.8]$} & $\mathrm{m} / \mathrm{s}$ \\
$m$ & 58 & $\mathrm{~kg}$ \\
$h$ & 0.085 & 1 \\
$A$ & 998.76 & $(\mathrm{~kg} \cdot \mathrm{m}) / \mathrm{s}^{2}$ \\
$B$ & 0.08 & $\mathrm{~m}$ \\
$k$ & 819.62 & $\mathrm{~kg} / \mathrm{s}^{2}$ \\
$\varkappa$ & 510.49 & $\mathrm{~kg} /(\mathrm{ms})$ \\
\hline
\end{tabular}


Mugapenak eta arazo intrintsekoak

Oinezkoen dinamika azaltzeko aproposa den arren, zenbait mugapen ditu ereduak. Batzuetan, egoera egonkorrak (clusterrak) eratzen dituzte oinezkoek, zerotik hurbil dagoelako indar netoa. Ereduan ez da Newtonen akzio/erreakzio printzipioa betetzen anisotropia medio eta, zenbaitetan, oinezkoak gainezarri egiten dira, indar alderatzailea oso txikia bada, edo oszilatu egiten dute indar hori handia bada. Nahiz eta azken arazo hori konstanteen aukeraketa egokiarekin erabat murriztu daitekeen, eta minimi- zatu, bi efektu horiek inoiz ez dira nuluak [19].

\section{PROBLEMAREN PLANTEAMENDUA ETA EBAZPENA}

Ate bakarreko gela baten ebakuazioa aztertu da. Helburua bikoitza da: alde batetik, eredua egiaztatzea; eta, bestetik, ebakuazio-prozesuan oztopoek nola eragiten duten ikustea.

Aztertutako gelaren dimentsioak honako hauek dira:

$$
\Omega=[0 \mathrm{~m}, 20 \mathrm{~m}] \times[0 \mathrm{~m}, 15 \mathrm{~m}]
$$

eta atea 2. irudian ikus daitekeen moduan, $(x, y)=(20,7.5)$ posizioan dago, $d \omega=0.5 \mathrm{~m}$-ko zabalerarekin. 2 . irudian gelaren oinarrizko geometria ageri da.

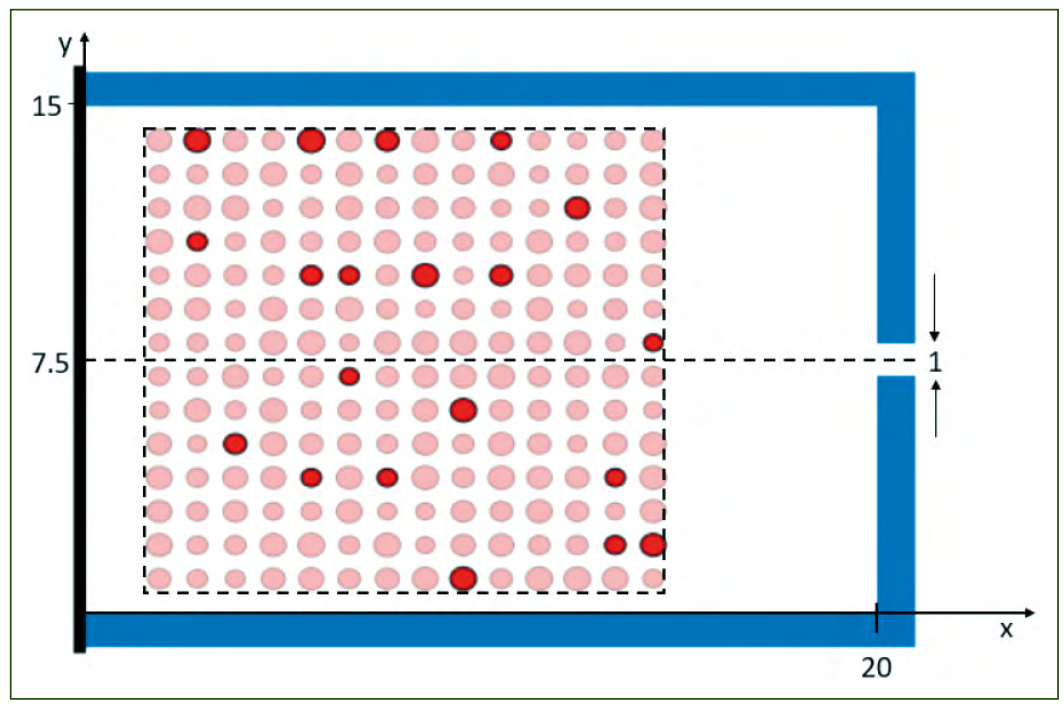

2. irudia. Larrialdi-kasuak aztertzeko erabiliko den gelaren geometria. Zenbait oinezko ausaz markatu dira haien ibilbidea ikusteko. 
Hasierako egoeran, $(x \in[1,14] \times y \in[1,14])$ karratuaren barruan kokatuta daude oinezkoak, antzeztoki batean, adibidez, zutik begira egongo balira bezala (bestelako konfigurazioak ere aztertu zitezkeen [20]). Sare baten bidez diskretizatzen da espazio hori, pertsonako espazioa $1 \mathrm{~m}^{2}$-ko tokiak izateko, ikuskizunean dagoen bitartean. Guztira, beraz, $14 \times 14=196$ toki daude.

Gela definitzen duten hormez aparte zenbait oztopo definitu da. Bi motatakoak hartu dira aintzakotzat:

- Zutabeak: geometria zirkularrekoak. Zentroko $(x, y)$ posizioaren eta erradioaren $(r)$ bidez parametrizatu dira. Ikusi 3. irudia.

- Hormak: geometria errektangeluarrekoak. Horien luzerak $(l)$, zabalerak $(\omega)$, atea dagoen hormarekiko $x$ ardatzeko distantziak $(d)$ eta atearen ardatzetik $y$ altuerak $(s)$ zehazten dute haren posizioa. Ikusi 4. irudia.

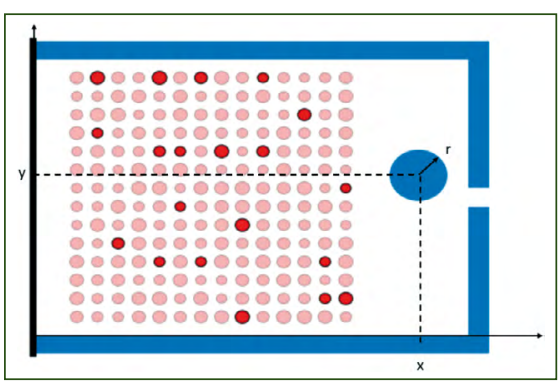

3. irudia. Zutabe erako oztopo baten parametrizazioa $x, y$ eta $r$ aldagaien bitartez.

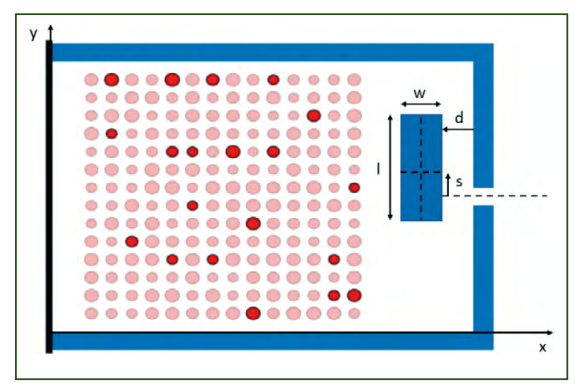

4. irudia. Horma erako oztopo baten parametrizazioa $l, d, \omega$ eta $s$ aldagaien bitartez.

Problema honetan funtsezkoa da indar abiarazlea ondo definitzea. Indar abiarazlea definitzen duen 3. ekuazioak sinplea dirudien arren, ez dago argi desiratutako norabidea nola aukeratu. Hori dela eta, oinezko guztiak puntu bakar batera zuzentzean, esaterako, pilaketak eratzen dira (bereziki korridoreak estutzean edota korridoreen izkinetan).

Lan honetan, oinezkoak atera zuzentzeko irizpidea honakoa izan da. Atea $\left(7.5-d_{\omega} / 2,7.5+d_{\omega} / 2\right)$ posizioan dagoela jakinda, $d_{\omega}$ atearen zabalera izanik eta $r_{i}$ ibiltari bakoitzaren erradioa, honako puntuak dituen lerroa eratu da atearen planoan:

$$
l=\left\{x=20.0, y=\left(7.5-\frac{d_{w}}{2}+r_{i}, 7.5+\frac{d_{w}}{2}-r_{i}\right)\right\}
$$


Aldiune bakoitzean, $i$. oinezkoa eta $l$ lerroaren arteko distantzia minimoko puntua kalkulatzen da eta bertara zuzentzen da ibiltaria. Prozedura hori eraginkorra da eta emaitza errealistak lortzen dira. Baina kontuan hartu behar da, askotan, oinezkoarentzat atea ez dagoela ikusgai. Ondorioz, tarteko helmugak ipini behar dira, atearen kasuan azaldu den prozedura berberari jarraituz.

Bi motatako simulazioak egin dira:

- Beteta: 196 guneak beteta daude; ondorioz, 196 ibiltari daude gela barruan.

- Erdi-beteta: gelan 100 oinezko bakarrik daude; beraz, soilik gune batzuk daude beteta.

Problema ebazteko 1. ekuazioa, bigarren mailako ekuazio diferentzial bektoriala, $\dot{\vec{y}}=f(\vec{y}, t)$ forman idatzi da. Egoera-bektore bat definitu da, $N$ ibiltarien informazio guztia biltzen duena (posizioa, abiadura, erradioa, desiratutako abiadura). Ekuazio-sistema ebazteko laugarren ordenako Runge-Kutta metodoa (ekuazio diferentzialen ebazpenerako zenbakizko metodo oso zabaldua) erabili da, denbora pausoa $h=0,085$ izanik.

\section{EMAITZAK ETA ANALISIA}

Lan honetan [21]. erreferentzian agertzen den konfigurazioa hartu da oinarritzat. Bertan 3 egoera aztertzen dira: (a) horma bat ate ondoan kokatuta, (b) zutabe bat ate ondoan ipinita eta (c) oztoporik gabeko kasua. Artikuluon, pareta eta zutabe horien posizio optimoa bilatzen da eboluzio diferentziala, Differential evolution (DE), optimizazio-metodoaren bitartez $[21,22]$. Lan honetan, posizio optimo horien antzeko balioak aintzakotzat hartuta, lehenengo esperimentuan, egoera hori errepikatu da. Esperimentu horri L0. Esperimentua deitu zaio. Behin hori bibliografiakoarekin bat datorrela egiaztatatutakoan, hurrengo esperimentuetan, zutabe eta hormen posizioa aldatu da eta haien kopurua ere bai.

Azterketa egiteko, esperimentu bakoitzean hiru egoera ezberdin aztertu dira, haien arteko aderaketa egin ahal izateko. Esperimentu bakoitza 4 grafikotan laburtu da: lehenengo 3 irudietan, egoeren konfigurazioa eta parametroak adierazi dira. Bertan, era aleatorioan aukeratutako zenbait oinezkok jarraitutako ibilbidea markatu da. 4. irudian, berriz, adierazi da konfigurazio bakoitzean irtendako ibiltari kopurua, denboraren funtzioan.

\section{L0 - Oinarrizko Esperimentua}

6. irudian ikus daitekeen moduan, $N=196$ oinezkoren kasuan, (a) egoera, hau da, horma daukan konfigurazioa da eraginkorrena. Hala ere, 
aipatzekoa da, hasiera batean, egoera hori dela txarrena, zeren eta oinezkoek denbora luzeago behar duten atera heltzeko, bete beharreko distantzia handiagoa delako. Hori 5. irudian beha daiteke. Bestalde, printzipioz, harritzekoa izan daiteke oztoporik gabeko konfigurazioa txarrena izatea. Era erraz batean azaltzen da: oztopoek fluxua ordenatzea lortzen dute eta, beraz, oinezkoak arinago ateratzea lortzen dute [21].

(a) $l_{a}=2, l=10.00, d=1.00, w=0.20, s=0.00$

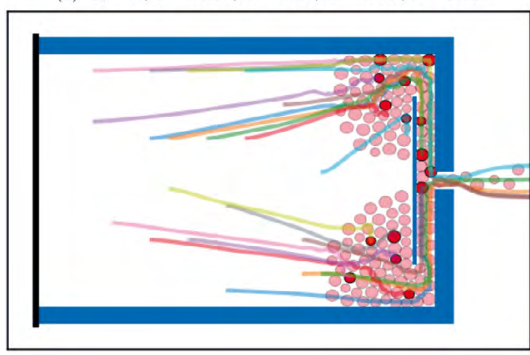

(c)

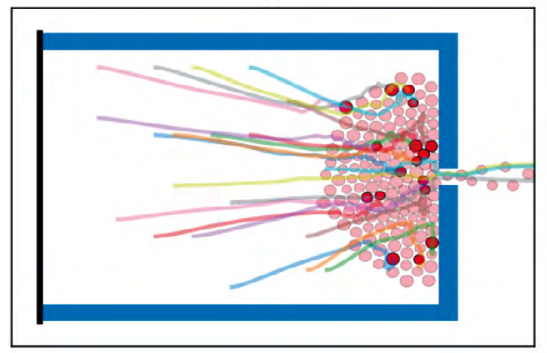

(b) $x=17.60, y=8.70, r=1.40$

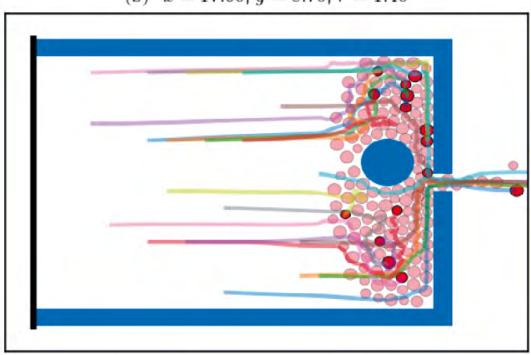

Irtendako oinezkoen kopurua

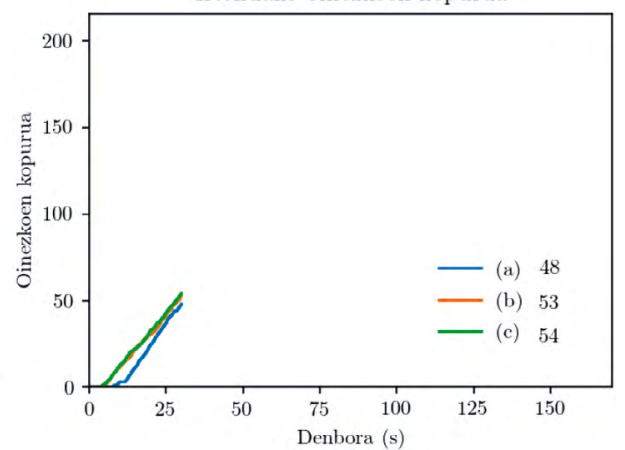

5. irudia. L0. Esperimentua: $N=196$ oinezkorekin $t=30 \mathrm{~s}$ igaro ondoren.

Aipatu beharrekoa da denbora pasa ahala oinezkoen irtete-ratioa txikiagotzen dela (6. irudiko 4. grafikoko malda txikiagotuz doa denboraren funtzioan). Batzuetan, atearen ondoan eratzen diren clusterren ondorio dira horiek. Izan ere, aldiune batzuetan ez aurrera ez atzera gelditzen dira cluster horiek.

Aldiz, $N=100$ kasuan, zutabearen (b) konfigurazioa da efizienteena. Hori ez da harritzekoa. Izan ere, $N=196$ oinezkoen kasuan, 6. irudiko laugarren grafikoari erreparatzen bazaio, oinezko kopurua 100 denean, 3 egoerak nahiko parekatuta daude. Ondorioz, hasierako kokapenaren arabera, bata edo bestea izan daiteke eraginkorrena. 
(a) $l_{a}=2, l=10.00, d=1.00, w=0.20, s=0.00$

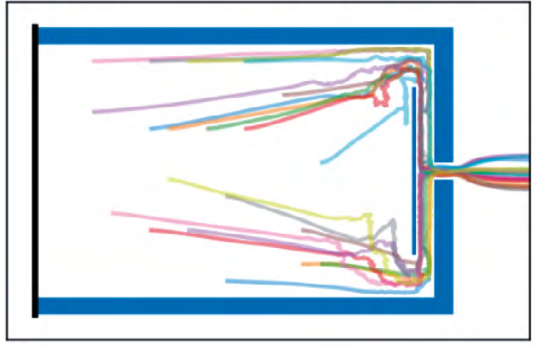

(c)

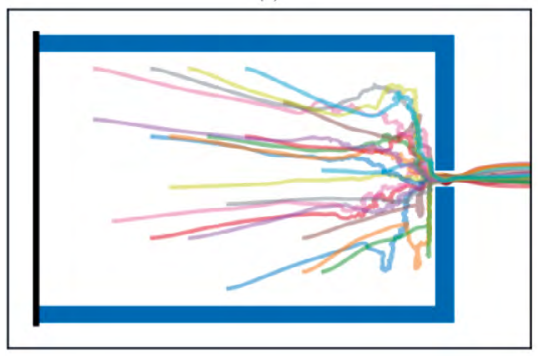

(b) $x=17.60, y=8.70, r=1.40$

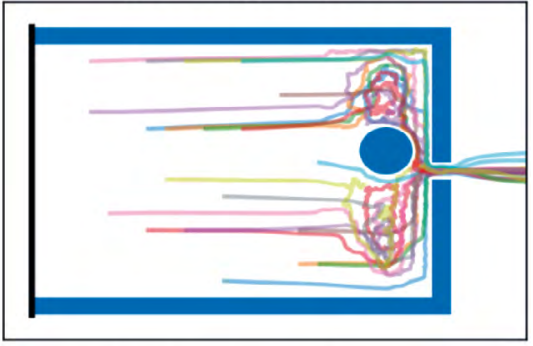

Irtendako oinezkoen kopurua

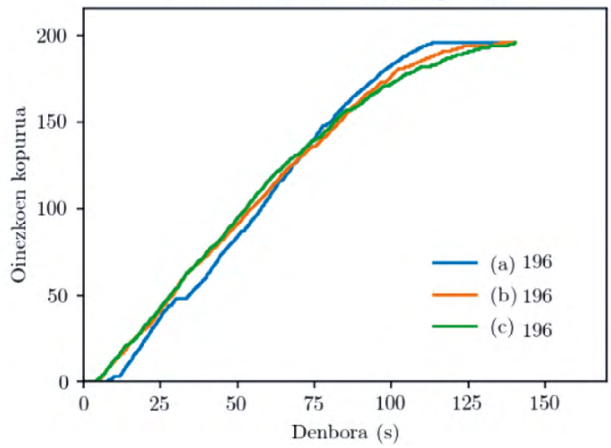

6. irudia. L0. Esperimentua: $N=196$ oinezkorekin amaierako egoera.

Behin ikusita horma bat ate aurrean kokatzeak onurak dituela, horma horren posizioa eta tamaina aldatu da bi faktore horiekiko mendekotasuna ikusteko.

\section{L1 - Hormaren distantzia atearekiko}

Hormaren $d$ distantzia, hau da, atearekiko $x$ distantzia aldatu da. Gainerako parametroak, L0. Esperimentukoaren berdinak izan dira. $d=1 \mathrm{~m}$ (L0. Esperimentukoa), $d=2 \mathrm{~m}$ eta $d=4 \mathrm{~m}$ kontsideratu dira.

Esperimentu honetan argi ikusten da, bai $N=196$ (ikusi 8. irudia) bai $N=100$ kasuan, L0.

Esperimentuko konfigurazioa dela eraginkorrena. Hau da, fluxua ordenatzea nahi badugu, atetik gertu jarri behar da horma. Izan ere, horma urrun ipinita, $d=4 \mathrm{~m}$-ra esaterako, fluxua ez da ordenatzea lortzen eta oztoporik gabeko kasuan bezala, atearen aurrean pilatzen dira ibiltariak 7 . irudian beha daitekeen moduan. 
(a) $l=10.00, d=1.00, w=0.20, s=0.00$

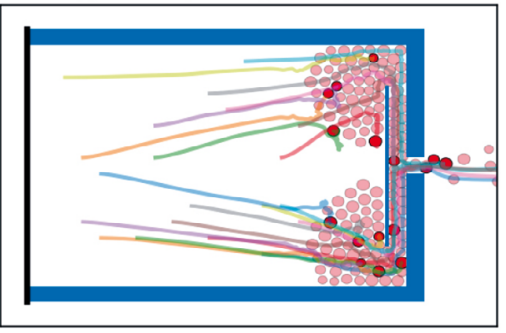

(c) $l=10.00, d=4.00, w=0.20, s=0.00$

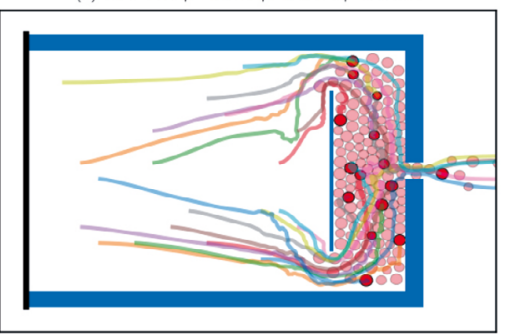

(b) $l=10.00, d=2.00, w=0.20, s=0.00$

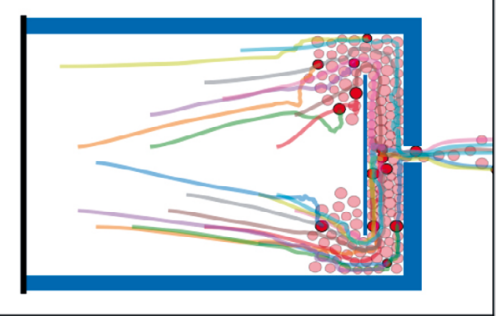

Irtendako oinezkoen kopurua

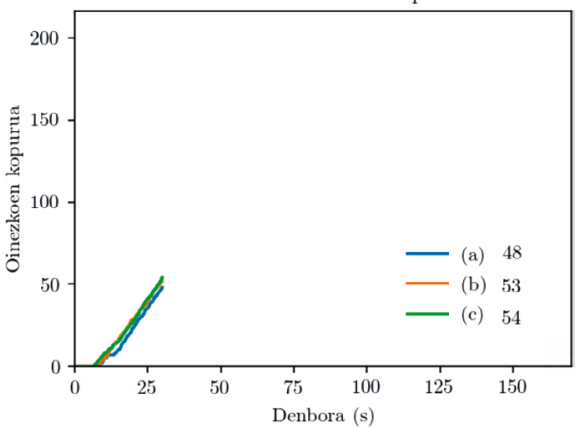

7. irudia. L1. Esperimentua: $N=196$ oinezkorekin $t=30 \mathrm{~s}$ igaro ondoren.

(a) $l=10.00, d=1.00, w=0.20, s=0.00$

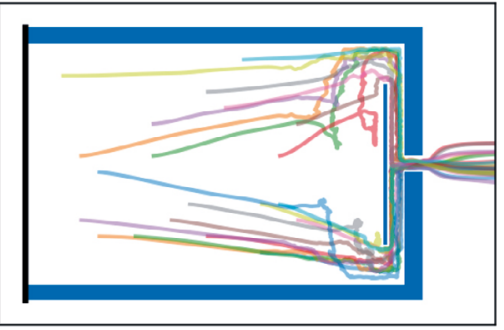

(c) $l=10.00, d=4.00, w=0.20, s=0.00$

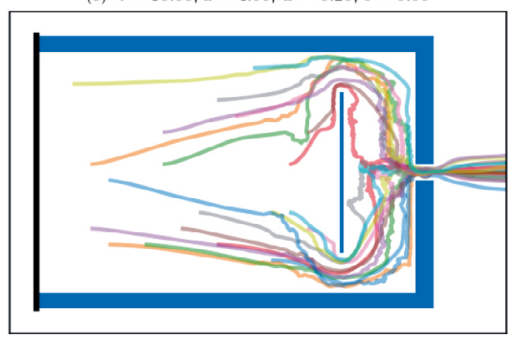

(b) $l=10.00, d=2.00, w=0.20, s=0.00$

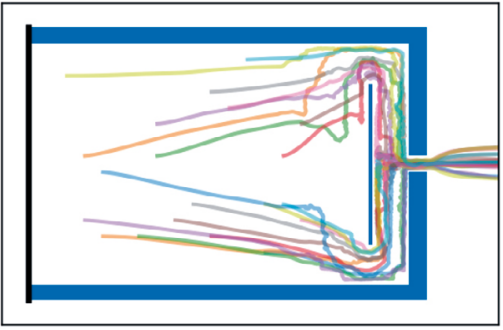

Irtendako oinezkoen kopurua

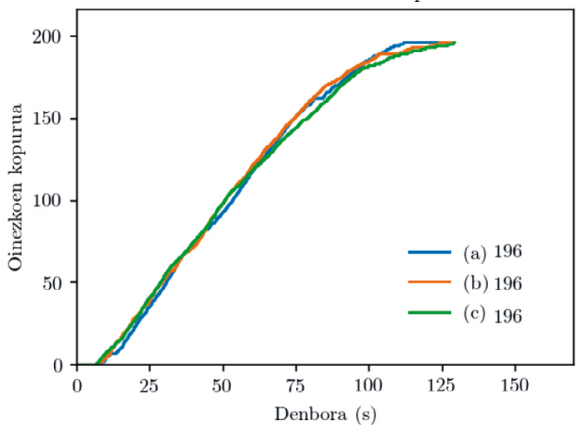

8. irudia. L1. Esperimentua: $N=196$ oinezkorekin amaierako egoera. 


\section{L2 - Hormaren luzera}

Esperimentu honetan hormaren luzera aldatu da, eta gainerako parametroak bere horretan utzi dira. $l=10 \mathrm{~m}, l=6 \mathrm{~m}$ eta $l=3 \mathrm{~m}$ aintzat hartu da.

Berriro ere, L0. Esperimentuko balioa, hots, $l=10 \mathrm{~m}$, da eraginkorrena. Luzera txikiagoko hormek ez dute emaitza onik ematen. 9. irudian azter daitekeen moduan: horma luzea denean, oinezkoak sigi-saga formazioan kokatzen dira bi hormen artean. Horma txikiaren kasuan, aldiz, banan-banan antolatzen dira eta, horregatik, irtete-abiadura motelagoa da.

(a) $l=10.00, d=1.00, w=0.20, s=0.00$

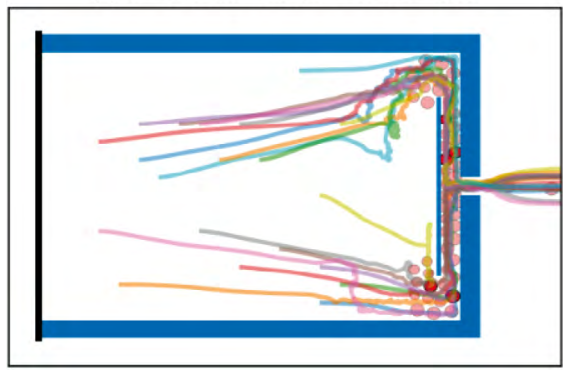

(c) $l=3.00, d=4.00, w=0.20, s=0.00$

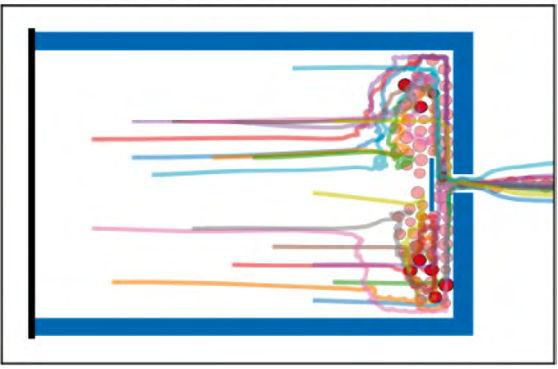

9. irudia. L2. Esperimentua: $N=196$ oinezkoren kasuan $t=72.6 \mathrm{~s}-$ ko egoera.

\section{L3 - Hormaren simetria atearekiko}

Esperimentu honetan hormaren atearen ardatzarekiko $s$ posizioa aldatu da. L0. Esperimentuan justu atearen simetrikoki zegoen kokatuta horma $(s=0)$. Orain, beste bi kasu aztertu dira, horma gora $s=0.5 \mathrm{~m}$ eta $s=1 \mathrm{~m}$ eramanez. Simetria ardatzetik horma desplazatzeak ez du laguntzen. Izan ere, gora eramatean, beheko partean oinezko gehiago pilatuko dira eta horiek irteteko denbora luzeagoa beharko dute.

\section{L4 - Hormaren zabalera}

Hormen konfigurazio desberdinekin bukatzeko, 4. Esperimentu honetan, hormaren w zabalera aldatu da. L0. Esperimentuko $\omega=0.2 \mathrm{~m}-\mathrm{z}$ gain, $\omega=1 \mathrm{~m}$ eta $\omega=2 \mathrm{~m}$ aztertu dira.

Kasu honetan, horma zabalagoak lagungarriak direla ikusi da. Izan ere, fluxua are gehiago ordenatzen da, ez soilik y norabidean baizik eta zabalera horregatik $x$ norabidean ere (ikusi 8 . irudia).

Behin hormaren eragina aztertuta, hurrengo esperimentuetan, zutabe bakarraren parametroak aldatuko dira, haien eragina aztertzeko. Betiere, L0. Esperimentuko zutabearen balioak hartuko dira oinarritzat, hots, $x=17.6, y=8.7$ eta $r=1.4 \mathrm{~m}$. 
(a) $l=10.00, d=1.00, w=0.20, s=0.00$

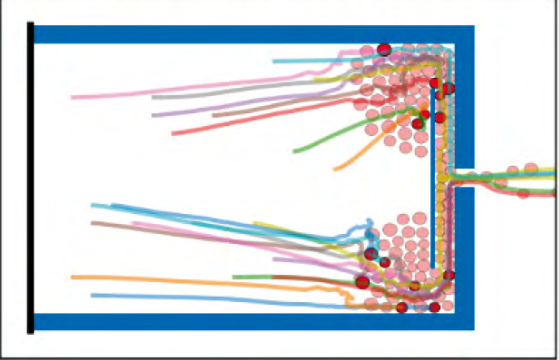

(c) $l=10.00, d=1.00, w=2.00, s=1.00$

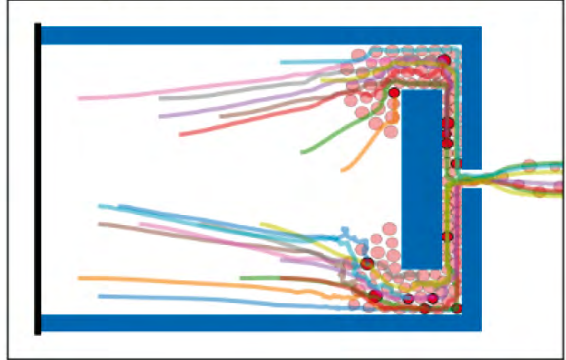

10. irudia. L4. Esperimentua: $N=196$ oinezkoren kasuan $t=42.5 \mathrm{~s}$-ko egoera.

(a) $x=17.60, y=8.70, r=1.40$

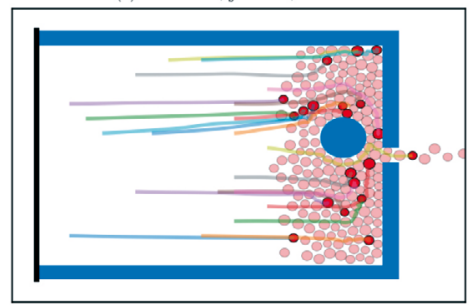

(c) $x=17.60, y=8.70, r=0.25$

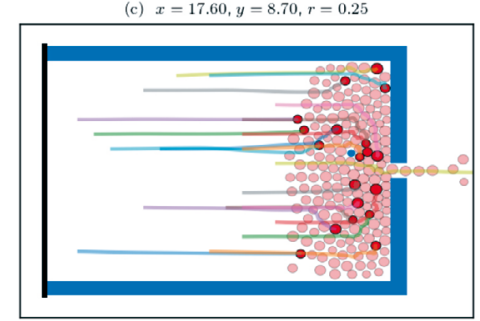

(b) $x=17.60, y=8.70, r=0.50$

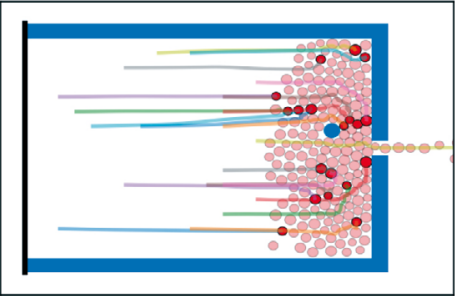

Irtendako oinezkoen kopurua
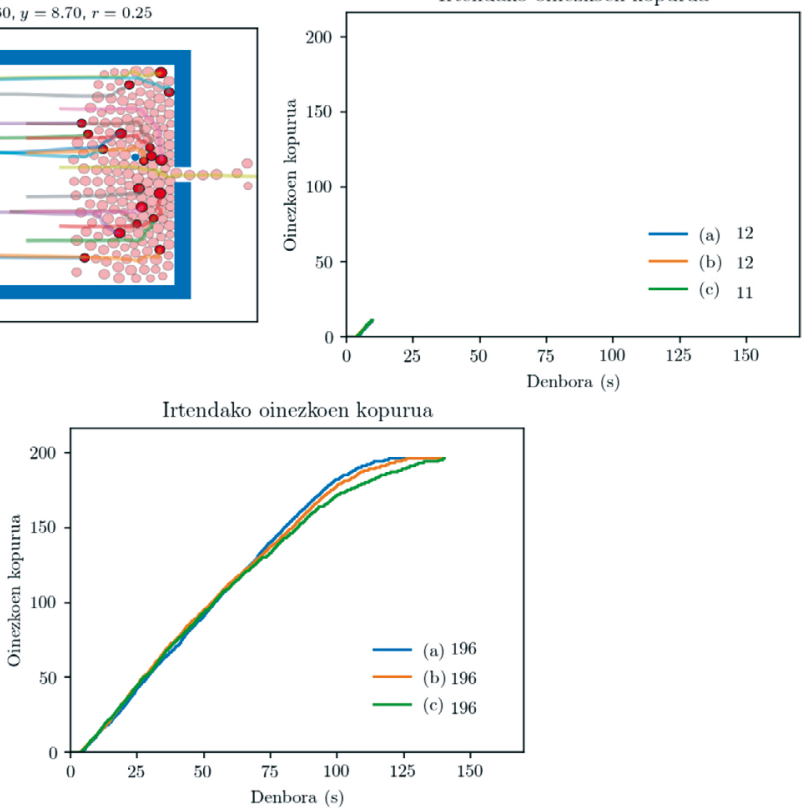

11. irudia. L5. Esperimentua: $N=196$ oinezkoren kasuan. Goiko 4 grafikoetan $t=11 \mathrm{~s}-$ ko egoera adierazi da. Behean irtendako ibiltari kopurua denboraren funtzioan amaierako egoeran. 


\section{L5 - Zutabearen erradioa}

Esperimentu honetan zutabearen erradioa aldatu da. $r=1.4 \mathrm{~m}$-ko erradioaz gain, $r=0.5 \mathrm{~m}$ eta $r=0.25 \mathrm{~m}$ hartu dira.

Zutabearen erradioaren murrizketak ez du laguntzen fluxua ordenatzen, 11. irudian ikus daitekeenez. Zenbat eta erradioa txikiagoa izan, orduan eta denbora gehiago behar dute ibiltariek gela ebakuatzeko. Izan ere, erradioa oso txikia baldin bada, oztoporik gabeko egoerara hurbiltzen gara.

\section{L6 - Zutabearen y posizioa}

Oraingoan, zutabearen $y$ posizioa aldatu da. L0. Esperimentuan zutabe hori ez zen justu atearen aurrean ipintzen $(y=8.7)$. Kasu honetan, ate aurrean, hots, $y=7.5$ eta $y=10$ posizioan ipini da. Esperimentu honetan, konfigurazio ezberdinen artean ez da diferentzia nabarmenik behatu eta kasu guztietan antzeko irtete-denborak lortu dira.

\section{L7 - Zutabearen $x$ posizioa}

Zutabearen posizio desberdinekin bukatzeko, zutabea $x$ ardatzean zehar mugitu da, $x=16.6, x=17.6$ eta $x=17.85$ hartuz. Berriro ere, L6. Esperimentuan gertatzen zen bezala, ez da diferentzia aipagarririk aztertu.

Orain arte egindako esperimentu guztietan atearen zabalera $1 \mathrm{~m}$-koa izan da. Ondoren, horren eragina aztertuko da.

\section{L8 - Atearen zabalera}

L0. Esperimentuaren parametro berdinak hartu dira baina atearen zabalera bikoiztu da: $2 \mathrm{~m}$-koa bihurtu da.

(a) $l_{a}=2, l=10.00, d=1.00, w=0.20, s=0.00$

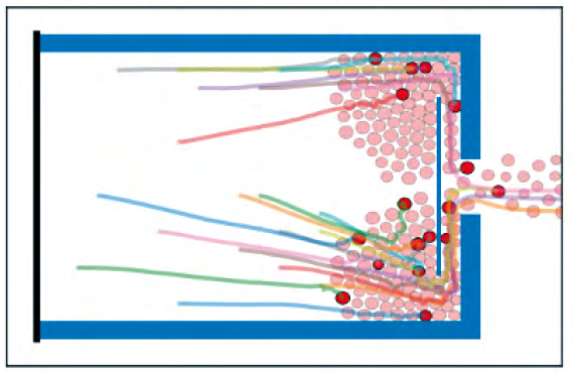

(c)

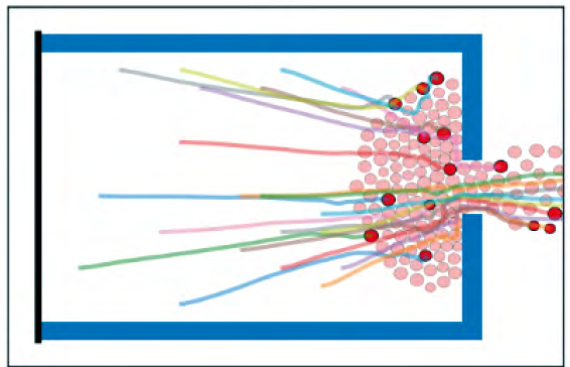

12. irudia. L8. Esperimentua $N=196$ oinezkoren kasuan $t=13.77 \mathrm{~s}$-ko egoera.

Kasu horretan, oztoporik gabeko konfigurazioa da eraginkorrena. Hori gertatzen da kasu honetan horma oso gertu dagoelako esperimentu honetan dagoen atearen zabalerarako. 12. irudiari erreparatuz, irteten diren oinezko 
kopurua mugatzen du hormak. Izan ere, ibiltarien bi ilara sortzen dira, baina atearen zabalerak aldiunero 3 oinezko irtetea ahalbidetzen du. Ondorioz, horma d distantzia handiago batera ipini beharko litzateke. Esperimentu honetan, beraz, argi ikusten da, besteak beste, hormaren $d$ distantzia eta atearen zabalera erlazionatuta daudela.

Bukatzeko, beste esperimentu bat egin da, baina kasu honetan hormen eta zutabeen kopurua handituz.

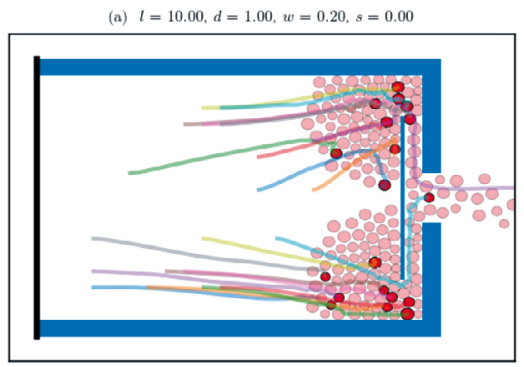

(b) $l=2.00, d=1.00, w=0.20, s_{1}=0.0, s_{2}=4.0, s_{3}=-4.00$

(c) $x=18.00, r=1.00, y_{1}=3.5, y_{2}=7.5, y_{3}=11.5$
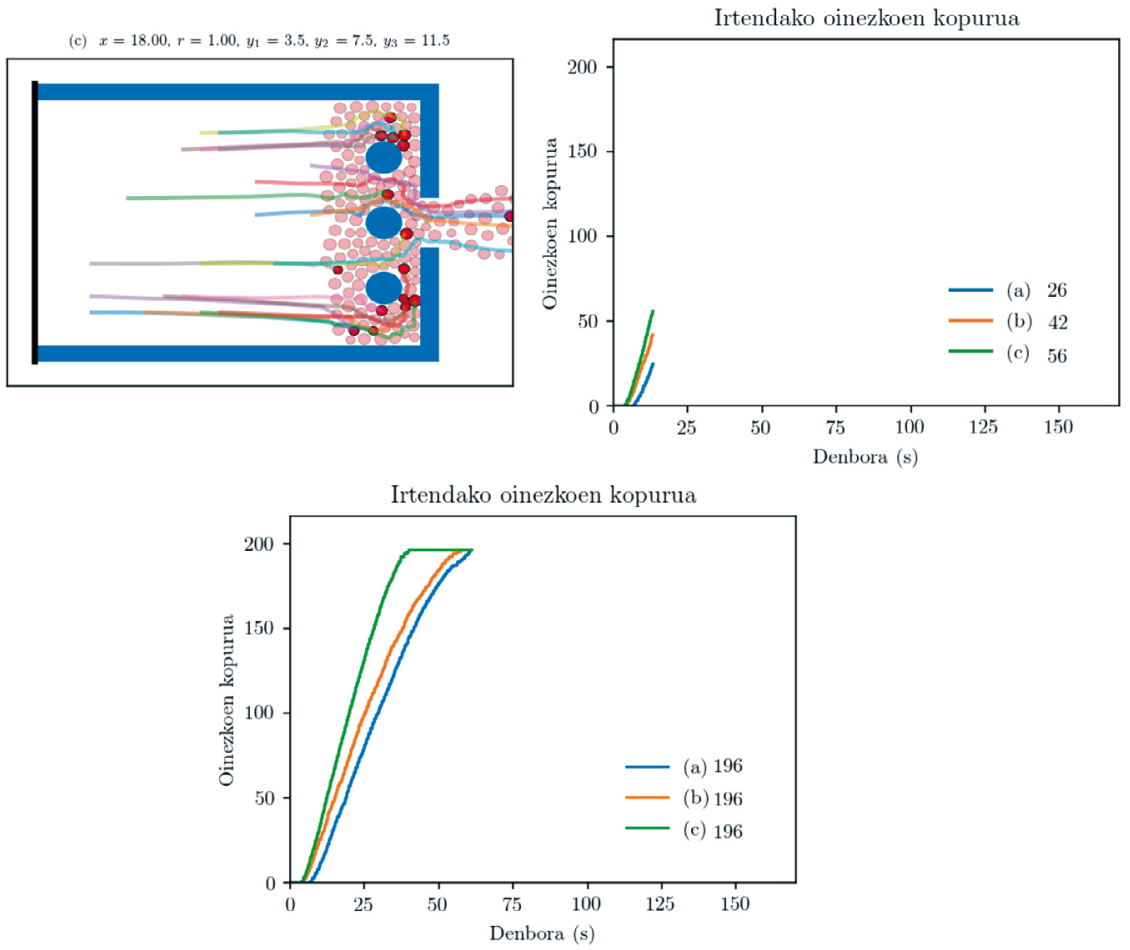

13. irudia. L9. Esperimentua: $N=196$ oinezkoren kasua. Goiko 4 grafiketan $t=15 \mathrm{~s}-\mathrm{ko}$ egoera adierazi da. Behean, amaierako egoerari dagokion irtendako ibiltari kopurua ageri da, denboraren funtzioan. 


\section{L9 - Lerrokatutako oztopoak}

Zutabe luze bat ipini beharrean, antzeko papera jokatzen duten 3 zutabe edo horma txikiagok nola jokatzen duten ikustea da esperimentu honen helburua. Konfigurazioa zehatza 13. irudian agertzen da.

Erreparatuz gero 13. grafikoari, argi ikusten da 3 zutabeak direla efizienteenak. Baliteke L8. Esperimentuan azaldu den atearen zabalerarekin berriro ere zerikusia izatea horrek. Izan ere, kasu horretan berriro ere atearen zabalera $d_{\omega}=2 \mathrm{~m}$-koa da. Hala ere, bai lerrokatutako 3 zutabeek zein hormatxoek fluxua ordenatzea lortzen dute era efizientean, lau taldetan banatzen baitituzte oinezkoak.

\section{L10 - Lerrokatutako hormak}

Azkeneko esperimentu honetan justu atearen altueran horma bat izan beharrean, espazio librea uztea erabaki da bertatik oinezkoak igarotzeko. Ondorioz, horma luzea bi zatitan banandu da konfigurazio horietako batean. Beste biak ohiko horma luzea eta L9. Esperimentuko lerrokatutako 3 hormatxoak izan dira (ikusi 14).

Emaitzari erreparatzen bazaio, emaitza oso antzekoa lortzen dute lerrokatutako 3 hormatxoek eta 2 hormek eta, beti, horma luzeak lortutakoa baino hobea. 
(a) $l=10.00, d=1.00, w=0.20, s=0.00$

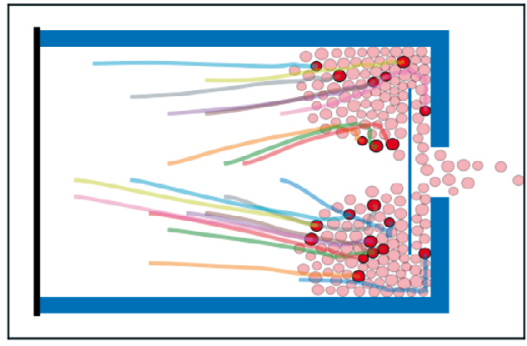

(b) $l=2.00, d=1.00, w=0.20, s_{1}=0.0, s_{2}=4.0, s_{3}=-4.00$

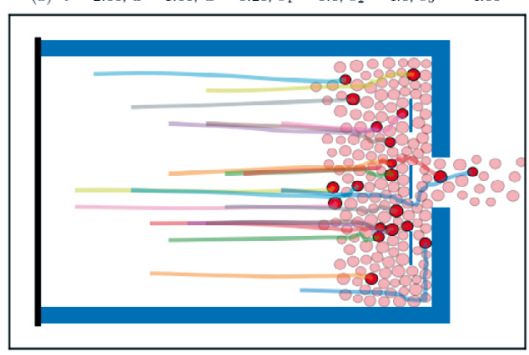

(c) $l=4.50, d=1.00, w=0.20, s_{1}=3.25, s_{2}=-3.25$

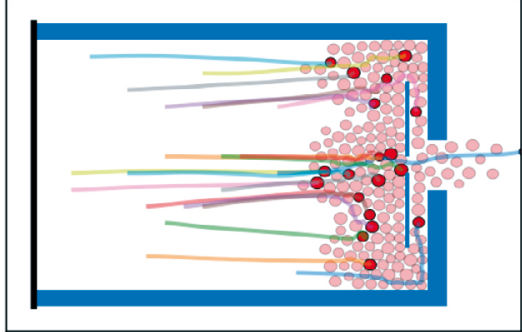

Irtendako oinezkoen kopurua

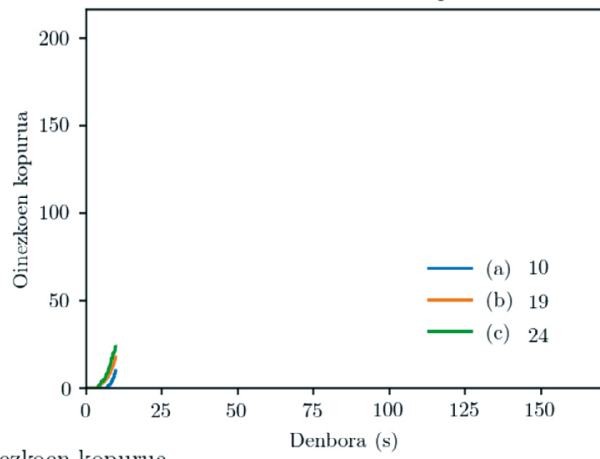

Irtendako oinezkoen kopurua

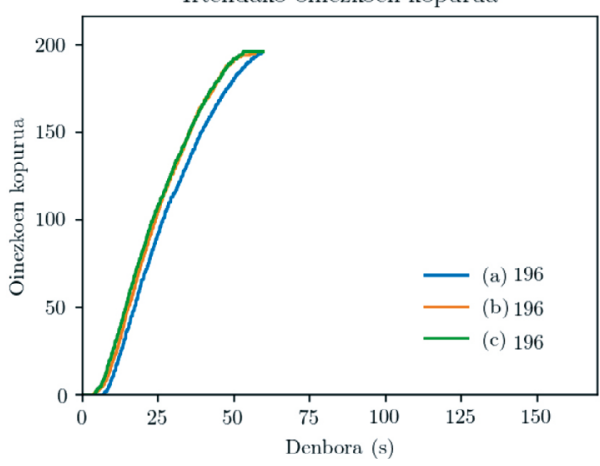

14. irudia. L10. Esperimentua: $N=196$ oinezkoren kasua. Goiko 4 grafiketan $t=11$ s-ko egoera adierazi da. Behean ageri da amaierako egoerari dagokion irtendako ibiltari kopurua, denboraren funtzioan.

\section{ONDORIOAK}

Lan honetan ikusi da Social Force Model eredua erabilgarria dela oinezkoen dinamika aztertzeko larrialdi-egoeretan eta, beraz, segurtasuna hobetzeko. Lortutako ondorioak honako hauek izan dira: 
- Atearen ondoan oztopoak ipintzeak fluxua ordenatzen laguntzen du eta, ondorioz, eraginkorragoak dira larrialdietan tokiak husteko.

- Horma bakarraren kasuan, atearekiko simetrikoki kokatu behar da oztopoa, atearen zabaleraren arabera $d$ distantziara. Izan ere, atearen zabalerak hormaren atearekiko $d$ distantzia horretan eragin handia du. Horrez gain, luzera eta zabalera handikoa izan behar du hormak, fluxua hobeto ordenatze aldera. Kasu zehatz horretan, parametro egokienak $l=10 \mathrm{~m}, \omega=2 \mathrm{~m}, s=0 \mathrm{~m}$ eta $d=1 \mathrm{~m}$ izan dira, hormaren zabalera $d_{\omega}=1 \mathrm{~m}$ izanik.

- Zutabearen kasuan, erradio txikiko oztopoek ez dute eraginik. $r=1.34 \mathrm{~m}$ izan da aztertutako parametroen artean egokiena. Bestalde, atetik hurbil kokatzea komenigarria da, $x=17.6, y=8.7$ posizioaren inguruan, baina ez da ikusi eragin handirik azken parametro horietan.

- Egindako esperimentuetan, horma luzeen ordez, lerrokatuta dauden horma txikiagoak edo zutabeak efizienteagoak izan dira.

Hala ere, lortutako emaitza horiek guztiak kualitatiboak dira eta, oinezkoen hustutze-denbora minimizatzeko eta, benetan, gela bateko konfigurazio optimoena bilatzeko, egoera ugari aztertu beharko lirateke, oztopoen parametro guztiak aldi berean kontsideratuz. Mota honetako problemak ebazteko, bilaketa teknika heuristikoak egokiak dira, ohiko metodoekin nekez lor daitezkeen emaitzak eskuratzen direlako. Esaterako, aipatutako eboluzio diferentziala algoritmo aproposa da hurrengo bi abantailak medio: alde batetik, soluzio optimoa lor daiteke hasierako baldintza guztietarako eta bestetik, konbergentzia azkarra du.

\section{BIBLIOGRAFIA}

[1] GONZÁLEZ, J.D. 2011. Estudio de modelos para tráfico peatonal y su aplicación a pasillos en diferentes escenarios. Universidad Autónoma Metropolitana, Ciudad de México.

[2] CASTEllanO, C., FORTUNATO, S. eta LORETO, V. 2009. «Statistical physics of social dynamics». Reviews of Modern Physics, 81, 591-646.

[3] HOOGENDOORN, S.P., LUDING, S., BOVY, P.H.L., SCHRECKENBERG, M. eta WOLF, D. 2007. Traffic and granular flow'03. Springer Science and Business Media, Berlin.

[4] SCHADSCHNEIDER, A., KLINGSCH, W., KLÜPFEL, H., KRETZ, T., ROGSCH, C. eta SEYFRIED, A. 2011. Evacuation Dynamics: Empirical Results, Modeling and Applications. Encyclopedia of complexity and systems science. Springer, Berlin.

[5] HANKIN, B.D. eta WRIGHT, R.A. 1958. «Passenger Flow in Subways». Journal of the Operational Research Society, 9, 81-88. 
[6] HENDERSON, L.F. 1971. «The statistics of crowd fluids». Nature, 229, 381-383.

[7] HUGHES, R.L. 2000. «The flow of large crowds of pedestrians». Mathematics and Computers in Simulation, 53, 367-370.

[8] HUGHES, R.L. 2002. «A continuum theory for the flow of pedestrians». Transportation Research Part B Methodological, 36(6), 507-535.

[9] HOOGENDOORN, S. eta BOVY, P.H.L. 2000. «Continuum modeling of multiclass traffic flow». Transportation Research Part B Methodological, 34(2), 123-146.

[10] SCHRECKENBERG, M. eta SHARMA, S.D. 2001. Pedestrian and Evacuation Dynamics. Springer, Berlin.

[11] BURSTEDDE, C., KLAUCK, K., SCHADSCHNEIDER, A. eta ZITTARTZ, J. 2016. «Simulation of pedestrian dynamics using a two-dimensional cellular automaton. Physica A two-dimensional cellular automaton». Physica A, 295, 507-525.

[12] HELBING, D. eta MOLNÁR, P. 1995. «Social force model for pedestrian dynamics». Physical Review E, 51, 4282-4286.

[13] JOHANSSON, A. 2016. Bi-directional flow in the Social Force Model. Karlstads universitet, Karlstadt.

[14] TRIGO, M. 2017. Universality of the Fundamental Diagram in Pedestrian Dynamics A study based on social force models. Instituto de Física Interdisciplinar y Sistemas Complejos, Palma de Mallorca.

[15] GULIKERS, L., EVERS, J., MUNTEAN, A. eta LYULIN, A. 2013. «The effect of perception anisotropy on particle systems describing pedestrian flows in corridors». Journal of Statistical Mechanics: Theory and Experiment, 2013(04).

[16] JOHANSSON, A., HELBING, D. eta SHUKLA, P.K. 2007. «Specification of the social force pedestrian model by evolutionary adjustment to video tracking data». Advanced in Complex Systems, 10, 271-288.

[17] HELBING, D., FARKAS, I. eta VICSEK, T. 2000. «Simulating dynamical features of escape panic». Nature, 407, 487-490.

[18] STEINER, A., PHILIPP, M. eta SCHMID, A. 2007. «Parameter Estimation for a Pedestrian Simulation Model». 7th Swiss Transport Research Conference, 1-29.

[19] CHRAIBI, M. 2012. Validated force-based modeling of pedestrian dynamics. Forschungszentrum Jülich, Jülich.

[20] MEYERS, R.A. 2009. Encyclopedia of complexity and systems science. Springer, Berlin.

[21] ZHAO, Y., LI, M., LU, X., TIAN, L., YU, Z., HUANG, K., WANG, Y. eta LI, T. 2017. «Optimal layout design of obstacles for panic evacuation using differential evolution». Physica A: Statistical Mechanics and its Applications, 465, 175-194.

[22] STORN, R. eta PRICE, K. 1997. «Differential evolution-a simple and efficient heuristic for global optimization over continuous spaces». Journal of global optimization, 11(4), 341-359. 